\title{
ФАКТОРИ, ЩО ВПЛИВАЮТЬ НА ПОКАЗНИКИ ЯКОСТІ ПОЛИЦЕВОЇ ОРАНКИ
}

\author{
Соколік Сергій Петрович \\ старший викладач \\ Сумський національний аграрний університет \\ ORCID: 0000-0003-4496-8681 \\ e-mail: Sokolik1009@gmail.com \\ Руденко Віктор Аркадійович \\ кандидат технічних наук, доцент \\ Сумський національний аграрний університет \\ ORCID: 0000-0001-7319-2451 \\ e-mail: rudvik1942@ukr.net
}

В статті досліджено вплив на показники якості полицевої оранки таких параметрів машинного агрегату, як: швидкість руху агрегату, встановлена глибина оранки, тип агрофону. Аналіз даних польового досліду дав можливість визначити оптимальні параметри швидкості руху грунтообробного агрегату та глибини обробітку, при яких забезпечується більший кут обертання пласта грунту, менша гребенистість та глибистість поверхні поля.

Так само, як і за теоретичними уявленнями для звичайної оранки зростання глибини оранки знижувало, а підвищення швидкості руху збільшувало кут обертання пласта.

Швидкість руху агрегату впливає на показники гребенистості і глибистості поверхні поля, зі зростанням швидкості на обох типах агрофону значення цих показників, хоч і не суттєво, але зменшувались.

При оранці по чорному пару показники якості роботи плуга виявилися теж кращими за оранку стерньового фону: гребенистість поля зменшувалась в діапазоні 11,0 - 9,4\% проти 14,3 - 10,8\%; глибистість поля зменшувалась в діапазоні $21,0-18,1 \%$ nроти $25,0-21,5 \%$.

Ключові слова: обробіток грунту, плуг, якість обробітку, оранка, оборот пласта, гребенистість.

DOI: https://doi.org/10.32845/msnau.2021.1.8

Постановка проблеми. Аналіз наукових досліджень свідчить, що одним з головних резервів підвищення родючості ґрунту є забезпечення оптимальних грунтових умов. Від ефективності використання машини буде залежати як кінцева врожайність, за рахунок забезпечення машиною потреб культури в цілому, так і собівартість виробництва продукції рослинництва (витрати паливно-мастильних матеріалів, продуктивність, затрати робочого часу) [1, 2].

Актуальним постає питання: як зменшити собівартість виконання механізованої технологічної операцій, при цьому, зберегти продуктивність роботи агромашини та не втратити у якості виконання операції. Тому актуальною є проблема проведення відповідних досліджень і розробка рекомендацій для ефективного виконання основного обробітку грунту.

Аналіз останніх досліджень і публікацій. Питанням підвищення якості полицевої оранки та зниженню енерговитрат на оранку присвячені роботи багатьох вчених $[2,3,5]$. Питаннями комбінування робочих органів, диференціації способів обробітку грунту за шарами, визначення діючих сил і агротехнічних показників роботи різних грунтообробних знарядь займалося багато вчених [4-6]. Аналіз наведених джерел дозволяє сфрормулювати висновки про ступінь розробленості обраної теми і намітити мету досліджень.

При полицевій обробці констатується вища врожайність культур, що обумовлює компромісне рішення багатьох вчених та аграріїв застосовувати технології з чергуванням у міру необхідності відповідно до засміченості полів, ущільнення ґрунту, утворення плужної підошви та інших факторів. Полицева оранка буде застосовуватися в найближчому майбутньому приблизно на половині площ. Основні напрямки вдосконалення плугів стосуються створення оборотних знарядь, смугових відвалів, комбінованих органів, застосування вібрації, але покращенню обороту пласта присвячується менше уваги.

Повний оборот пласта вважається переважним способом від полицевої оранки, він все більше поширюється при основному обробітку, але до цього часу реалізований тільки у створенні фронтальних плугів. Фронтальні плуги мають свої недоліки, що стримують їх широке поширення, і потрібні пошуки інших, більш простих конструкцій, що забезпечують надійність технологічного процесу при зміні параметрів знаряддя.

Існують способи збільшення кута обороту пласта за рахунок зміни ширини захвату корпусів, застосування передплужників, кутознімів, бічного зміщення передплужників, зміни форми відвалу тощо, але вони призводять лише до часткового обороту, залишаючи резерв для подальших досліджень $з$ даної теми.

Мета досліджень - $€$ дослідження впливу на якісні показники роботи полицевого плуга таких параметрів, як: швидкість руху агрегату, встановлена глибина обробітку грунту, тип агрофону.

Результати досліджень. При оранці чорної пари вологість ґрунту на глибині від нуля до 30 см змінювалася від 11 до 17\% і твердість - від 0,13 до 0,94 МПа. Досліди на стерні проводилися в умовах низької вологості грунту та, як наслідок, досить високої твердості. Умови випробувань: трактор ХТЗ 17221, плуг ПЛН-5-35, фон поля - пар та стерня озимої пшениці, глибина оранки варіювалася від 18 до 26 см, швидкість руху - від 6 до 10 км/год, вологість та твердість грунту на глибині від нуля до 30 см змінювалися відповідно від 8 до 15\% та від 0,32 до 0,97 МПа.

Густота пожнивних залишків і ступінь їх загортання у ґрунт вимірювалися підрахунком кількості стебел усередині 
рамки розмірами 0,5×0,5 м, накладеної на полі у випадковому місці з трьома повтореннями.

У пластів, що розпадаються, їх кут перевороту можна визначити лише орієнтовно за положенням найбільших брил. За стандартом він вимірюється як кут нахилу скошеної сторони у борозни. Якщо перед проходом плуга встромити вертикально в грунт вішки довжиною, що дорівнює глибині оранки, то після проходу плуга можна оцінити їх кут перевороту.

Гребнистість зораної поверхні, виміряна в поперечному напрямку, характеризується висотою гребенів, що залишаються, або брил. Цей показник вимірювався відносною величиною подовження ламаної лінії, що копіює гребені, порівняно з відстанню між початком і кінцем вимірювань $[7,8]$.

Гребнистість обробленої поверхні оцінювали вимірюванням подовження шнура при копіюванні рельєфу поверхні ґрунту. Для цього на замірюваному майданчику забивали кілочок і прив'язували до нього шнур із мірною стрічкою на кінці. Шнур натягували поперек напряму обробки та на відстані 10 м забивали другий кілочок. Якщо довжина натягнутого шнура між кілочками дорівнювала 10 м, то при звільненні шнура його довжина між кілочками збільшувалася внаслідок копіювання нерівностей поверхні ріллі. Подовження шнура визначали за мірною стрічкою. Відношення подовження шнура (см) до базової його довжини (м) дає відсоток гребнистості ріллі $[7,8]$.

Глибистість поверхні обробленого поля визначається квадратною метровою рамкою, що накладається на поверхню. У наших дослідах застосовувалася та ж рамка, що і при вимірі відсотка загортання рослинних решток. Всі брили діаметром більше 5 см, які знаходяться в площі рамки, заміряли по довжині та ширині з точністю до 1 см, а потім обчислювали площу, яку вони займали $[7,8]$. Про величину глибистості поверхні поля судять по відношенню до сумарної площі брил із зазначеним розміром до площі рамки, вираженому у відсотках. За агровимогами, допустима межа глибистості 10 - 15\%.

Для агротехнічної оцінки плуга він був випробуваний у польових умовах. Умови проведення випробувань наведено у таблиці 1.

Таблиця 1. Умови проведення польових випробувань плуга на оранці чорної пари

\begin{tabular}{|c|c|}
\hline Показники & Значення показників \\
\hline Склад агрегату & ХТ317221 + ПЛН-5-35 \\
\hline \begin{tabular}{|l|} 
Характеристика умів: \\
- тип ґрунту та назва по механічному \\
складу \\
- рельєфф \\
- мікрорельєфф \\
- попередник
\end{tabular} & $\begin{array}{c}\text { Вилужений чорнозем } \\
\text { Рівний, ухил } 1^{\circ} \\
\text { Вирівняний } \\
\text { Чорна пара }\end{array}$ \\
\hline \begin{tabular}{|c|} 
- вологість ґрунту, \% \\
у шарі 0-10 см \\
у шарі $10-20$ cм \\
у шарі $20-30$ см \\
\end{tabular} & $\begin{array}{l}11 \\
13 \\
17 \\
\end{array}$ \\
\hline \begin{tabular}{|c} 
- твердість ґрунту. МПа \\
у шарі 0-10 cм \\
у шарі $10-20 \mathrm{~cm}$ \\
у шарі $20-30 \mathrm{~cm}$ \\
\end{tabular} & $\begin{array}{l}0,13 \\
0,71 \\
0,94 \\
\end{array}$ \\
\hline $\begin{array}{l}\text { Маса рослинних та пожнивних зали- } \\
\text { шків, г/м² }\end{array}$ & 0 \\
\hline Температура повітря, град. & 15 \\
\hline
\end{tabular}

Гребенистість поверхні перевірялася шляхом накладання шнура поперек напрямку руху агрегату.

Кут обороту пласта визначали за допомогою кутоміру. Кутомір накладали на укіс борозни так, щоб його основа щільно прилягала до скосу борозни здебільшого довжини пласта. Кут вимірювали з числом повторів не менше 10 щоб похибка вимірювань не перевищувала $\pm 1^{\circ}$.

На відміну від чорного пару, стерньовий фон має набагато більшу твердість поверхневого шару і меншу вологість. Умови проведення випробувань на стерні наведені в таблиці 2. На цьому полі визначалися ті ж показники, що і при оранці чорного пару

При оранці чорного пару кут обороту пласта проглядається дуже неявно через повне розпушування шарів грунту, що обертаються. Протягом усього літа пар підтримувався в пухкому стані, особливо в поверхневому горизонті, ніякої рослинності не було, тому зв'язність грунту була недостатньою для утримання прямокутної форми перерізу пластів. Такий малозв'язний ґрунт сповзав з відвалу і формував насип з певним кутом скосу стінки борозни.

Вплив глибини оранки на кут обороту пластів під час роботи плуга вивчався за швидкості руху агрегату 6 км/год. В результаті вимірів виявилося, що зі збільшенням глибини обробки кут обороту пластів слабо зменшується, і цю залежність вважатимуться лінійною (рис. 1). Раніше наведені теоретичні дослідження для пластів із прямокутним перетином показали ту саму залежність, але більш явно виражену.

Таблиця 2. Умови проведення польових випробувань плуга на стерньовому фоні

\begin{tabular}{|c|c|}
\hline Показники & Значення показників \\
\hline Склад агрегату & ХТ317221 + ПЛН-5-35 \\
\hline $\begin{array}{l}\text { Характеристика умов: } \\
\text { - тип грунту } \\
\text { - рельєф } \\
\text { - мікрорельєфф } \\
\text { - попередник }\end{array}$ & $\begin{array}{c}\text { чорнозем } \\
\text { Рівний, ухил } 1^{\circ} \\
\text { Вирівняний } \\
\text { Пшениця }\end{array}$ \\
\hline $\begin{array}{c}\text { - вологість грунту, \% } \\
\text { в шарі 0-10 cм } \\
\text { в шарі } 10-20 \mathrm{~cm} \\
\text { в шарі } 20-30 \mathrm{~cm} \\
\end{array}$ & $\begin{array}{c}8 \\
12 \\
15 \\
\end{array}$ \\
\hline \begin{tabular}{|c} 
- твердість грунту, МПа \\
в шарі 0-10 см \\
в шарі $10-20$ см \\
в шарі $20-30$ см
\end{tabular} & $\begin{array}{l}0,32 \\
0,88 \\
0,97\end{array}$ \\
\hline Маса рослинних залишків, г/м² & 147 \\
\hline Висота пожнивних залишків, см & 15 \\
\hline Густота пожнивних залишків шт./ м² & 260 \\
\hline Температура повітря, град. & 11 \\
\hline
\end{tabular}

Вплив глибини оранки на кут обороту пластів під час роботи плуга вивчалося за швидкості руху агрегату 6 км/год. В результаті вимірів виявилося, що зі збільшенням глибини обробітку кут обороту пластів слабо зменшується (таблиця 4), і цю залежність вважатимуться лінійною (рис. 5). Раніше наведені теоретичні дослідження для пластів із прямокутним перетином показали ту саму залежність, але більш явно виражену.

Однак прямої аналогії тут немає, можна констатувати 
лише загальну тенденцію. Додатковий вплив на пласти передплужниками полегшує їх обертання, і зі збільшенням глибини оранки просто збільшується об'єм грунту, що перевертається, висота гребенів збільшується. Разом з цим збільшується крутість укосу борозни, що й реєструється як зменшення кута обороту пласта.

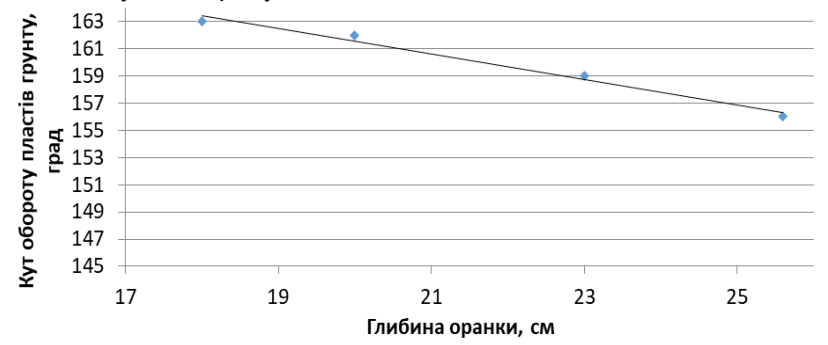

Рис. 1 - Вплив глибини оранки на кут обороту пластів (чорний пар)

За результатами дослідів виявилося, що швидкість руху агрегату сприяє перевороту пластів (рис. 2). 3 графіка видно, що кут обороту пластів зростав з $155^{\circ}$ до $163^{\circ}$ при підвищенні швидкості руху у всьому діапазоні від 6 до 10 км/год.

Такий результат можна пояснити тим, що зі збільшенням швидкості руху зростає кінетична енергія відкидання пластів убік, вони повністю руйнуються, і поверхня зораного поля стає більш вирівняною. Зі збільшенням швидкості кути укосів у борозен стають менш крутими, що у методиці стандарту вважається збільшенням кута обороту пластів.

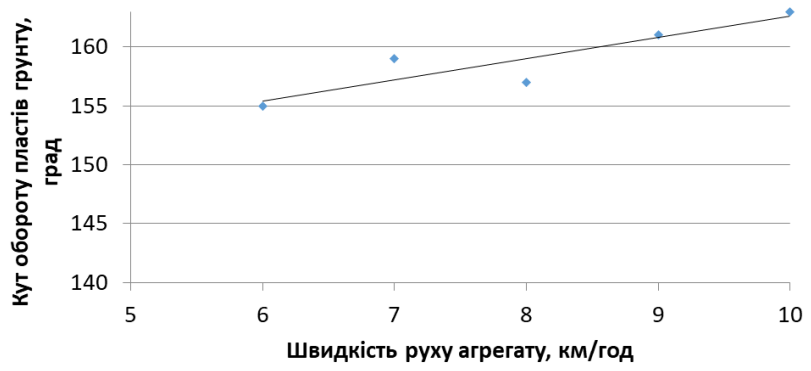

Рис. 2 - Вплив швидкості руху плуга на кут обороту пластів (чорний пар)

Грасрік зміни гребеністості залежно від швидкості орного агрегату для чорного пару наведено на (рис.3). 3 графіка видно, що показник гребенистості, хоч і не значно, але зменшується при підвищенні швидкості руху у всьому діапазоні від 6 до 10 км/год. Цей результат також можна пояснити тим, що зі збільшенням швидкості руху підвищується кінетична енергія відкидання пластів убік і вони краще кришаться, а значить поверхня поля стає більш вирівняною. Зменшення гребнистості поверхні поля полегшує наступний обробіток поверхні грунту при доведенні його до посівних кондицій.

Глибиситість поверхні також трохи зменшувалася при зростанні швидкості оранки через сильніше відкидання пластів убік і більшого їх руйнування (рис.4). Тенденція до незначного зниження величини цього показника спостерігалась у всьому швидкісному діапазоні.

Кут обороту пластів при оранці більш сухого і щільного грунту мав більший розкид, так як окремі брили часто займали довільне становище. Глибина обробки мало впливала на кут обороту пластів при оранці. Ця залежність вивчалася за швидкості руху агрегату 6 км/год.

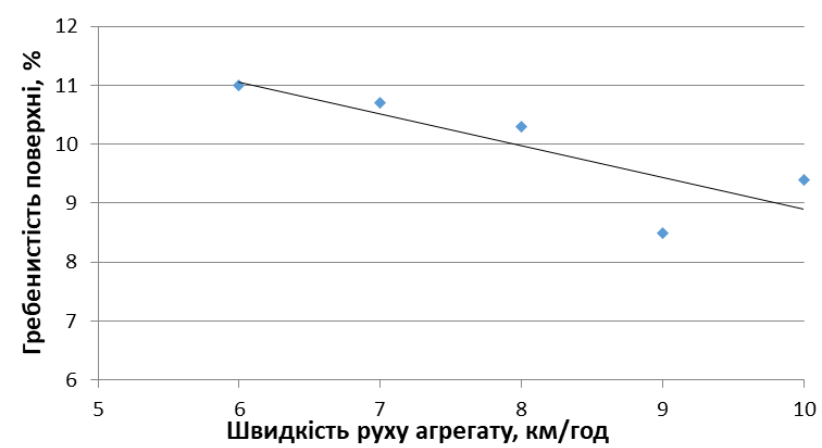

Рис. 3 - Залежність гребенистості поверхні залежно від швидкості руху агрегату

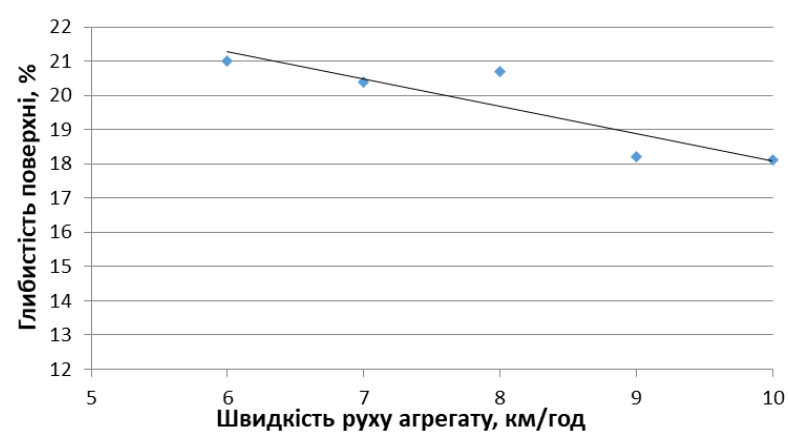

Рис. 4 - Залежність глибистості поверхні залежно від швидкості руху агрегату

Через велику глибистість збільшився розкид результатів вимірювань при загальній тенденції до зменшення кута (рис. 5). В результаті вимірів виявилося, що як і при обробітку по чорному пару, зі збільшенням глибини обробітку кут обороту пластів слабо зменшується і цю залежність також можна вважати лінійною.

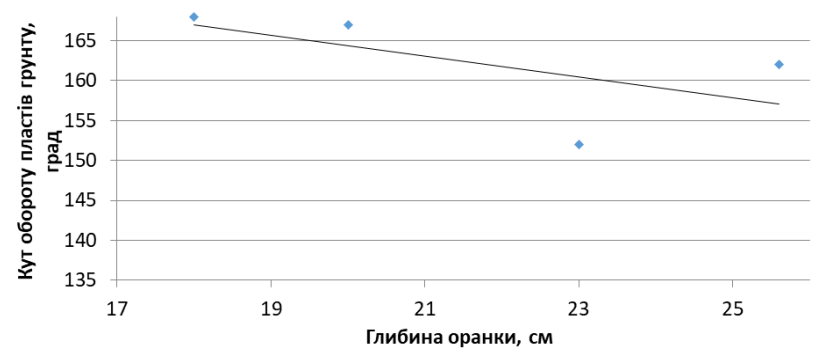

Рис. 5 - Вплив глибини оранки на кут обороту пластів (стерньовий фон)

Як і на фоні чорного пару, при роботі на стерні швидкість руху агрегату гарно впливає на переворот орного шару грунту, хоч і незначно в межах випробуваних швидкостей від 6 до 10 км/год (рис. 6).

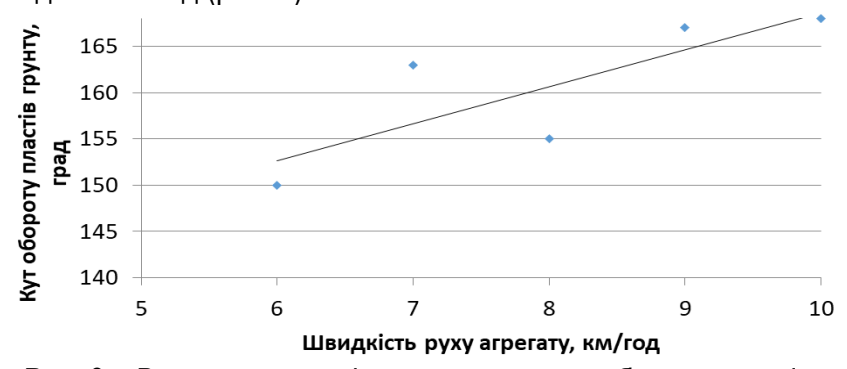

Рис. 6 - Вплив швидкості руху плуга на кут обороту пластів (стерньовий фон) 
Порівняно з попереднім дослідом проведеним на чорному пару гребнистість зораної поверхні по стерні збільшилася через меншу вологість та підвищену твердість грунту (рис. 7). Так само як і на попередньому агрофоні гребенистість зменшувалась при збільшенні швидкості руху орного агрегату.

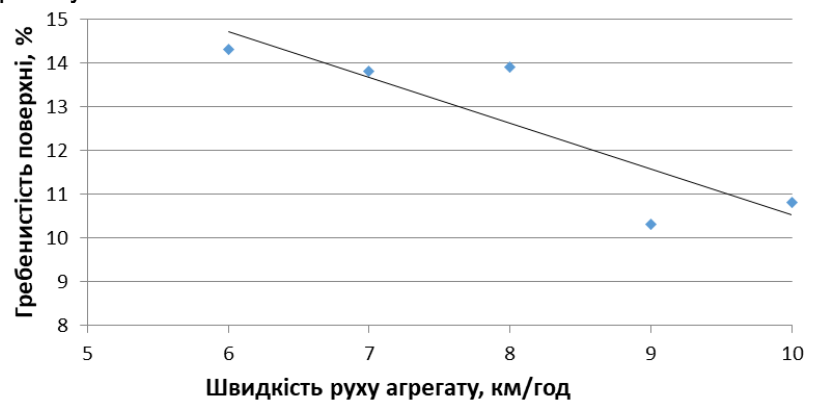

Рис.7 - Залежність гребенистості поверхні залежно від швидкості руху агрегату (стерньовий агрофон)

Показники глибистості поверхі поля після оранки по стерні також були вищими ніж при обробітку чорного пару і таксамо зменшувались при зростанні швидкості руху (рис. 8).

Висновки. Гіпотеза про поліпшення якісних показників оранки шляхом більшого кута обороту пластів підтвердилася. При оранці чорної пари досягнуто куту обороту пластів 156-163 порівняно з кутом $152-168^{\circ}$ при оранці стерні озимої пшениці.

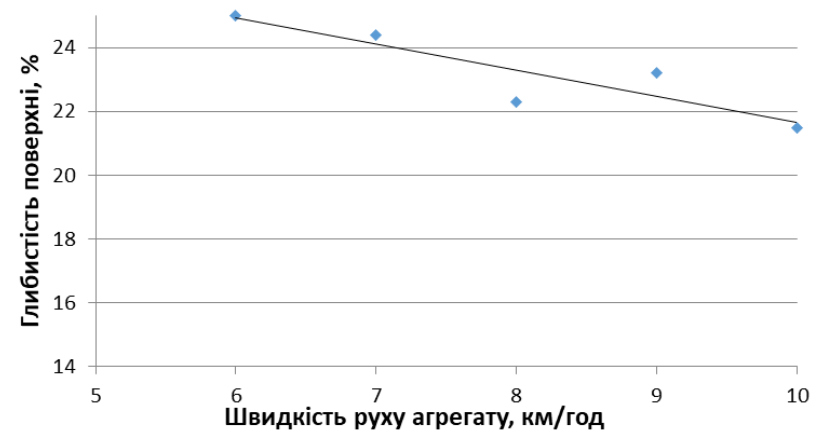

Рис.8 - Залежність глибистості поверхні залежно від швидкості руху агрегату (стерньовий агрофон)

Глибина оранки та швидкість агрегату впливали на кут обертання пластів так само, як і за теоретичними уявленнями: зростання глибини оранки знижує, а швидкість руху збільшує кут обертання.

Швидкість руху агрегату впливає на показники гребенистості і глибистості повенрхні поля, зі зростанням швидкості на обох типах агрофону занчення цих показників, хоч і не суттєво, але зменшувались.

При оранці по чорному пару показники якості роботи плуга виявилися теж кращими за оранку стерньового фону: гребенистість поля зменшувалась в діапазоні 11,0 - 9,4\% проти 14,3 - 10,8\%; глибистість поля зменшувалась в діапазоні $21,0-18,1 \%$ проти $25,0-21,5 \%$.

\section{Список використаної літератури.}

1. Сільськогосподарські та меліоративні машини: Підручник / [Д. Г. Войтюк, В. О. Дубровін, Т. Д. Іщенко та ін.]. - Київ: Вища освіта, 2004. - 544 с.

2. Булгаков В. М. Теорія і практика обробітку грунту в сучасних умовах / В. М. Булгаков, С. П. Танчик, В. Т. Надикто. // Механізація та електриффікація сільського господарства. - 2015. - №2. - С. 30-38.

3. Надикто В.Т. Аналіз рівноваги заднього та фронтального плугів у поздовжньо-вертикальній площині / В.Т. Надикто, О.І .Генов, А.М. Аюбов // Вісник Харківського державного технічного університету сільського господарства. - 2003. - № 21. - С. $105-112$.

4. Надикто В.Т. Механіко-технологічні аспекти оранки // Вісник аграрної науки. 2012. № 4. С. 56-60.

5. Надикто В. Науково-практичні аспекти оранки // Техніка і технології АПК. 2017. № 5. С. 10-15.

6. Булгаков В.М. Агрегатування плугів. К.: Аграрна наука, 2008. 152 с.

7. КНД 46.16.02.08 - 95 Техніка сільськогосподарська. Методи визначення умов випробувань УкрНдІПВТ им. Л. Погорілого, 1994. - 50 с.

8. КНД.46.16.02.-96. Техніка сільськогосподарська. Номенклатура показників якості. Дослідницьке, 1997, 58 с.

Sokolik S.P., Sumy National Agrarian University (Ukraine)

Rudenko V.A., Sumy National Agrarian University (Ukraine)

Factors affecting plowing quality indicators

The article investigates the influence of such parameters of the machine unit on the quality indicators of plowing as: speed of movement, set plowing depth, surface type. The analysis of the field experiment data made it possible to determine the optimal parameters of the tillage machine speed and tillage depth, which provide a greater angle of rotation of the soil layer, less ridge and depth of the field surface.

As well as according to theoretical ideas for plowing, the increase in plowing depth decreased, and increasing the speed of movement increased the angle of rotation of the soil layer.

The speed of the machine affects the crest and depth of the field surface. With increasing velocity on both types of surface, the values of these indicators, although not significant, decreased.

When plowing on a clean surface, the quality of plow performance was also better than plowing stubble background: the ridge of the field decreased in the range of 11.0 - 9.4\% against $14.3-10.8 \%$; the depth of the field decreased in the range of $21.0-18.1 \%$ against $25.0-21.5 \%$.

Key words: tillage, plow, tillage quality, plowing, soil layer turnover.

Дата надходження до редакції: 04.03.2021 